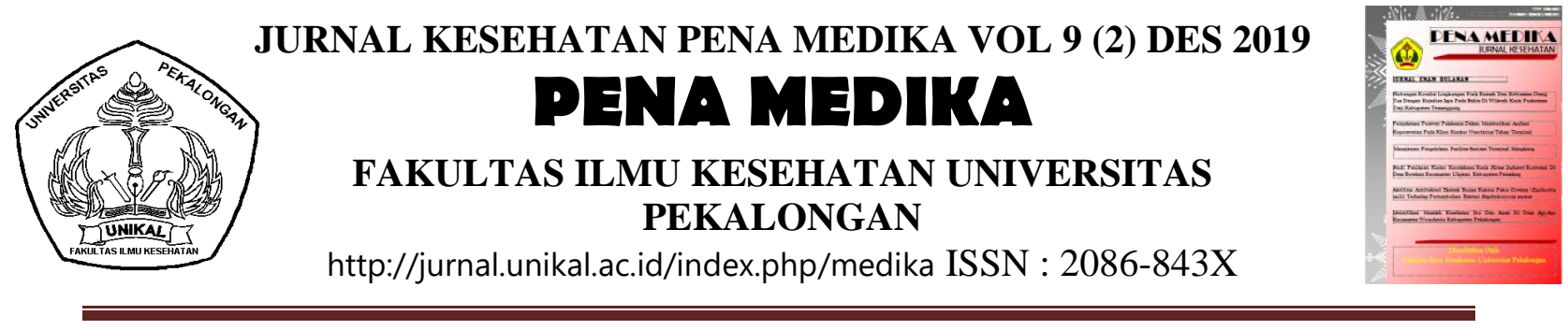

\title{
Pemetaan Daerah Status Gizi Bermasalah Di Kabupaten Batang Berbasis Analisis Spasial
}

\author{
Wahyuningsih $^{1}$, Dewi Nugraheni Restu Mastuti ${ }^{2)}$ \\ ${ }^{1)}$ Fakultas Ilmu Kesehatan Prodi Kesehatan Masyarakat Universitas Pekalongan

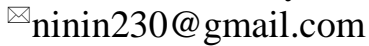

\begin{abstract}
ARTICLE INFO :

$\begin{array}{ll}\text { Accepted } & : 2019-11-13 \\ \text { Approve } & : 2019-11-24 \\ \text { Publish } & : 2019-12-1\end{array}$
\end{abstract}

\begin{abstract}
Continuous and comprehensive efforts need to resolve malnutrition problem in Indonesia. Riskesdas 2018, toddler nutrition problems were 17.7\%, Severely underweight (3.9\%) malnutrition (13.8\%). Although it has significantly decreased, specific locus require more specific interventions such as resolve malnutrition,BGM, BBLR. In Batang (BGM) increased 806 cases in 2018. Malnutrition increased to 129 cases BBLR infants were still dominant at 601 case in 2018. Purpose of research was to conduct mapping based on spatial analysis to determine areas that were prone to nutrition in Batang Regency. The method is secondary data processing from Dinas Kesehatan Kabupaten Batang in 2018 and then overlay with Quantum GIS software version 2.14.8. The result is an area with high malnutrition cases in Batang District at 36.08\% including (Puskesmas Batang I, II, III and IV). Areas with high BGM toddlers cases in 2 districts namely Blado District by $12.16 \%$ (including Puskesmas Blado I, II) and Batang District by 16.50\%. (including the areas of Batang I, II, III and IV). Areas that have a high BBLR predominance in Batang (Puskesmas Batang 1, Puskesmas Batang II and Puskesmas Batang IV) have BBLR cases of $20.13 \%$. The highest problem-prone areas of nutrition are in Batang District which includes 4 working areas of Puskesmas, namely Batang 1, II and IV and some Puskesmas Batang III. Interventions carried out by: Optimizing Posyandu, Periodic Home Visit to families with nutritional problems. Synergy of the 4 pillars (health, agriculture, economy and education) hopes that they can complexly overcome nutritional problems as a whole
\end{abstract}

\begin{abstract}
ABSTRAK
Upaya berkesinambungan dan komprehensif perlu dilakukan untuk mengatasi masalah gizi di Indonesia. Menurut Riskesdas 2018 masalah gizi balita sebesar 17,7 \%, gizi buruk $(3,9 \%)$ gizi kurang $(13,8 \%)$. Meskipun secara signifikan mengalami penurunan, lokuslokus khusus memerlukan intervensi yang lebih spesifik seperti mengatasi Gizi Buruk, BGM, BBLR. Di Kabupaten Batang balita Bawah Garis Merah (BGM) meningkat 806 kasus di tahun 2018. Gizi buruk meningkat menjadi 129 kasus Bayi BBLR masih dominan sebesar 601 bayi BBLR tahun 2018. Tujuan penelitian adalah melakukan pemetaan berbasis analisis spasial untuk mengetahui daerah yang mengalami rawan gizi di Kabupaten Batang. Metodenya dengan pengolahan data sekunder dari DinKes
\end{abstract}


Kabupaten Batang tahun 2018 kemudian dilakukan Overlay dengan software Quantum $G I S$ versi 2.14.8. Hasilnya adalah daerah dengan kasus gizi buruk tinggi di Kecamatan Batang sebesar 36,08 \% meliputi (Pusk. Batang I, II, III dan IV). Daerah dengan kasus balita BGM tinggi di 2 kecamatan yaitu Kecamatan Blado sebesar 12,16 \% (termasuk puskesmas Blado I, II) dan Kecamatan Batang sebesar 16,50 \%. (termasuk wilayah puskesmas Batang I, II,III dan IV)..Daerah yang memiliki dominan BBLR tinggi di kecamatan Batang (Puskesmas Batang 1, Puskesmas Batang II dan Puskesmas Batang IV) memiliki angka kasus BBLR sebesar 20,13\%. Daerah yang rawan gizi bermasalah paling tinggi berada di Kecamatan Batang yang meliputi 4 wilayah kerja puskesmas yaitu Puskesmas Batang 1, Puskesmas Batang II, Puskesmas Batang IV dan sebagian Puskesmas Batang III. Intervensi yang dilakukan dengan:Optimalisasi Posyandu, Home Visit berkala pada keluarga yang memiliki permasalahan gizi.,Sinergi 4 pilar (kesehatan, pertanian, ekonomi dan pendidikan) harapannya secara kompleks dapat mengatasi permasalahan gizi secara menyeluruh.

\section{PENDAHULUAN}

Pembangunan sumber daya manusia masih menjadi fokus utama pengembangan setelah pemenuhan sarana prasarana dalam peningkatan derajat kesehatan masyarakat. Salah satu indikator pembangunan kesehatan diIndonesia dapat dilihat dari Indeks Pembangunan Kesehatan Masyarakat (IPKM). Secara nasional IPKM di Indonesia membaik dalam 5 tahun terakhir meskipun mayoritas semua indikator masih memerlukan perbaikan. Termasuk didalamnya indikator kesehatan komprehensif (UHH, mortalitas, morbiditas, angka kematian kasar) dan indikator spesifik (angka kematian ibu, angka kematian bayi, angka kematian neonatal, angka kematian bayi dll). Secara dominan angka kejadian tersebut dipengaruhi oleh banyak faktor. Untuk kematian bayi dan balita juga dikaitkan dengan status gizi nya. (Kementrian Kesehatan Republik Indonesia 2019)

Permasalahan gizi di Indonesia masih menjadi masalah klasik dalam dunia kesehatan. Meskipun begitu perlu dilakukan upaya terus menerus dan komprehensif untuk menyelesaikannya. Menurut Riskesdas tahun 2018 prevalensi permasalahan gizi pada balita di Indonesia mengalami penurunan yakni $17,7 \%$, dengan gizi buruk sebesar $3,9 \%$ dan gizi kurang sebesar 13,8 \% . Hasil ini memang lebih baik dari laporan hasil riskesdas tahun 2013 dimana prevalensi status gizi bermasalah masih mencapai 19,6 \%. (Kementrian Kesehatan Republik Indonesia 2018). Pada permasalahan gizi secara spesifik, seperti stunting juga terjadi penurunan 
prevalensi pada anak balita dari 37,21\% di tahun 2013 menjadi 30,79 \% tahun 2018. Demikian juga apabila dibandingkan dengan data prevalensi stunting pada balita tahun 2016 yaitu 33,60\%. (Kementrian Kesehatan Republik Indonesia 2016)

Begitu juga terkait kegemukan (obesitas) pada anak balita juga mengalami perbaikan yaitu menurun dari $11,90 \%$ pada 2013 menjadi 8,04\% tahun 2018 . Akan tetapi Meskipun angka ini secara signifikan mengalami penurunan apabila dibandingkan dengan target pada Rencana Pembangunan Jangka Menengah Nasional (RPJMN) masih belum tercapai optimal. Selisih hasil yang belum tercapai ini lah yang masih perlu diusahakan pemerintah yang bekerjasama dengan kementrian kesehatan dan tentunya masyarakat untuk segera diatasi. (Kementrian Kesehatan Republik Indonesia 2018)

Keberhasilan dalam mengatasi permasalahan gizi ini menuntut kerjasama dari berbagai pihak termasuk stake holder terkait. Puskesmas menjadi garda terdepan dalam teknis penanganan status gizi balita ini dengan cara optimalisasi UKBM dan kerjasama antar bidang seperti bidang kesga dan gizi. Penanganan permasalahan status gizi balita ini akan lebih fokus dan terarah jika ada proses pengelompokan atau pemetaan khusus wilayah yang memang rentan status gizi bermasalah. Pemantauan status gizi balita sebenarnya sudah dilakukan oleh pemerintah, dapat dilihat dari data rutin yang dilaporkan setiap tahunnya yang merupakan angka cakupan status gizi baik tingkat kota dan kabupaten sedangkan data yang dikumpulkan dalam satu wilayah di Indonesia melalui riset kesehatan dasar. Penyajian data ini menjadi komponen paling penting dalam interpretasi dan menentukan program yang sesuai. Salah satu cara yang dapat mempermudah interpretasi ini adalah dengan mengolah data dengan menyajikan fakta wilayah dimana data tersebut dapat dipetakan melalui analisis spasial dengan Sistem Informasi Geografis (SIG) (Prahasta 2001)

Keluaran dari analisis ini adalah berupa peta wilayah daerah dengan status gizi bermasalah berdasar pada data rutin yang ada serta dilihat dari faktor lain yang berperan (Berat Bayi Lahir Rendah, balita dengan BGM dan Gizi Buruk). Kabupaten Batang merupakan kabupaten dengan permasalahan Gizi yang kompleks. Data mengenaai balita yang masih berada Dibawah Garis 
Merah (BGM) meningkat dari yaitu sebesar 798 kasus di tahun 2016, 746 kasus di tahun 2017 dan sebanyak 806 kasus di tahun 2019. Data mengenai balita yang mengalami gizi buruk meningkat dari tahun 2016 sebesar 120 kasus, tahun 2017 sebesar 129 kasus dan menurun di tahun 2018 sebesar 97 kasus. Bayi yang memiliki berat badan lahir rendah juga termasuk dominan sebesar 788 bayi BBLR tahun 2016, sebesar 607 bayi BBLR tahun 2017 dan sebesar 601 bayi BBLR di tahun 2018. (Dinas Kesehatan Kabupaten Batang 2018)

Zonasi dan pemetaan wilayah rentan mengalami permasalahan kesehatan lainnya khususnya di Indonesia masih memerlukan banyak kajian dengan berbagai tema masalah kesehatan. Sebaran penyakit atau permasalahan secara geografis dapat membantu stakeholder terkait dalam merumuskan dan menentukan rencana intervensi yang tepat. (Laurini \& Thompson 1992)

Kompleksitas dalam memahami fenomena penyakit atau kawasan rentan yang dapat diimplementasikan dalam ruang dan menjadi bagian perencanaan wilayah merupakan salah satu hal yang cukup rumit. akan tetapi itu semua dapat dilakukan dengan analisis menggunakan
Sistem Informasi Geografis (SIG) (Bohrer, Gill, Shachar Shem 2002). Pemetaan ini bertujuan untuk mengatahui sebaran daerah di Kabupaten Batang yang mengalami status gizi bermasalah yang dapat dilihat dari variabel data Balita di Bawah Garis Merah, Balita yang mengalami Gizi Buruk dan Bayi dengan Berat Badan Lahir Rendah (BBLR).

\section{METODE}

Data yang dianalisis merupakan data sekunder Dinas Kesehatan Kabupaten Batang tahun 2018. Analisis spaisal ini menggunakan aplikasi software Quantum Gis versi 2.14.8. Pengumpulan data yang dilakukan melalui laporan dari masing-masing puskesmas. Variabel yang dianalisis untuk dilayotkan dalam penelitian ini adalah status gizi balita meliputi Balita BGM, Balita yang mengalami gizi buruk dan Bayi BBLR. Sebelum analisis dilakukan terlebih dahulu verifikasi kelengkapan data dan dikelompokkan menurut puskesmas masing masing yang tersebar di wilayah Kabupaten Batang. Hasil analisis Univariat kemudian disimpan dalam bentuk Microsoft. Excel yang kemudian dilakukan pemetaan. Langkah yang perlu dilakukan adalah 
a.menyiapkan file dalam bentuk excel yang kemudian dilakukan join data b.setelah join data dilakukan kemudian melakukan klasifikasi pengkategorian/pembobotan daerah, c.setelah masing-masing variabel di layoutkan kemudian masing-masing peta dilakukan join peta yang menghasilkan peta baru proyeksi lokus yang mengalami status gizi bermasalah.(Astrini, Retno 2012)

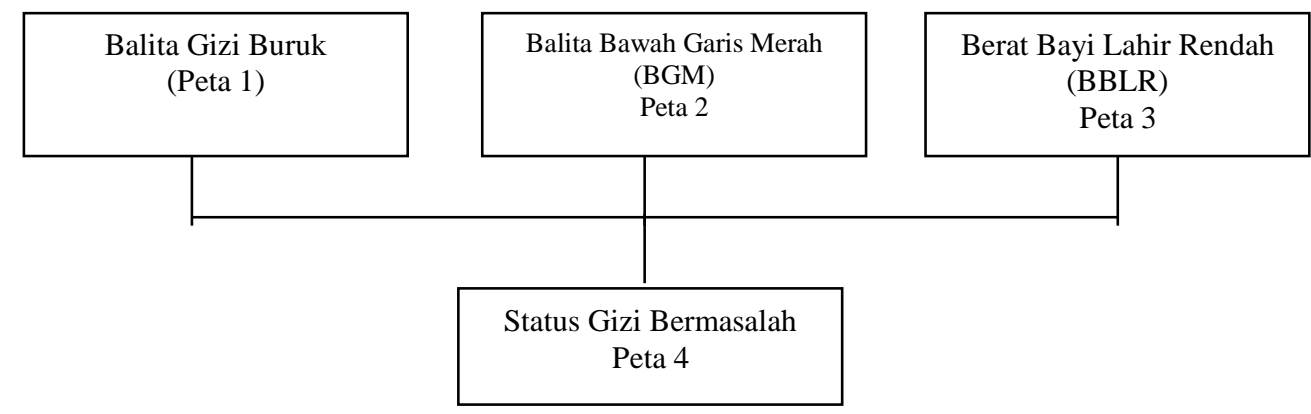

Gambar 1. Alur Analisis yang mempengaruhi daerah yang mengalami status gizi bermasalah

Tabel. 1 Definisi Variabel Rancangan Peta

\begin{tabular}{|c|c|}
\hline Peta & Keterangan \\
\hline $\begin{array}{l}\text { Peta } 1 . \\
\text { Kejadian Gizi Buruk Balita }\end{array}$ & $\begin{array}{l}\text { Sebaran kejadian gizi buruk di kabupaten Batang berdasarkan data } \\
\text { sekunder yang berada di Dinas Kesehatan Kab Batang dan } \\
\text { diklasifikasikan berdasarkan presentase 1) Rendah : } 1,03 \%-12,71 \\
\% \text {, 2) Sedang: } 12,72 \%-24,40 \%, 3) \text { Tinggi : } 24,41 \%-36,08 \%\end{array}$ \\
\hline $\begin{array}{l}\text { Peta } 2 . \\
\text { Balita Bawah Garis Merah } \\
\text { (BGM) }\end{array}$ & $\begin{array}{l}\text { Sebaran balita yang memiliki balita berada pada kondisi Bawah } \\
\text { Garis Merah (BGM) yang berada di Dinas Kesehatan Kab Batang } \\
\text { dan diklasifikasikan berdasarkan presentase 1)Rendah : } 1,24 \%- \\
6,33 \%, 2) \text { Sedang : } 6,34 \%-11,41 \%, 3 \text { ) Tinggi: } 11,42 \%-16,05 \\
\%\end{array}$ \\
\hline $\begin{array}{l}\text { Peta } 3 . \\
\text { Berat Badan Lahir Rendah } \\
\text { (BBLR) }\end{array}$ & $\begin{array}{l}\text { Sebaran bayi yang lahir dengan berat badan rendah dibawah } 2.500 \\
\text { gr. Data klasifikasikan berdasarkan presentase: 1)Rendah: } 2,83 \% \\
-8,60 \%, 2) \text { Sedang : } 8,61 \%-14,36 \%, 3 \text { ) Tinggi: } 14,37 \%-20,13 \\
\%\end{array}$ \\
\hline $\begin{array}{l}\text { Peta } 4 . \\
\text { Daerah Rawan Status Gizi } \\
\text { Bermasalah }\end{array}$ & $\begin{array}{l}\text { Peta hasil overlay/tumpang tindih dari peta } 1,2 \text { dan } 3 \text {. yaitu variabel } \\
\text { balita Gizi Buruk, Balita Bawah Garis Merah (BGM), dan BBLR. } \\
\text { Peta menggambarkan daerah rawan status gizi bermasalah di } \\
\text { Kabupaten Batang. }\end{array}$ \\
\hline
\end{tabular}


Tabel 2. Nilai Bobot

\begin{tabular}{|l|l|l|l|}
\hline No & Variabel & Klasifikasi dan Kode & Pembobotan \\
\hline 1 & Balita Gizi Buruk & $1,03 \%-12,71 \%$ & Rendah \\
& & $12,72 \%-24,40 \%$ & Sedang \\
& & $24,41 \%-36,08 \%$ & Tinggi \\
\hline 2 & BGM & $1,24 \%-6,33 \%$ & Rendah \\
& & $6,34 \%-11,41 \%$, & Sedang \\
& & $11,42 \%-16,05 \%$ & Tinggi \\
\hline 3 & BBLR & $2,83 \%-8,60 \%$ & Rendah \\
& & $8,61 \%-14,36 \%$ & Sedang \\
\hline 4 & Daerah Rawan & $14,37 \%-20,13 \%$ & Tinggi \\
& Status G,3\% & Rendah \\
& bermasalah Gizi & $4,4 \%-6,67 \%$ & Sedang \\
& \multicolumn{2}{|r}{} \\
\hline
\end{tabular}

analisis spasial dalam penelitian ini dilakukan dengan mengelompokkan daerah mana saja yang terpetakan memiliki presentase status gizi bermasalah (gizi buruk, BGM dan BBLR) dengan pembobotan berdasarkan presentase dan dibedakan pula antara jenis kelamin.

\section{HASIL DAN PEMBAHASAN}

Kabupaten Batang terletak pada $6^{\circ} 51^{\prime} 46^{\prime \prime}$ sampai $7^{\circ} 11^{\prime} 47^{\prime \prime}$ Lintang Selatan dan antara $109^{\circ} 40^{\prime} 19^{\prime \prime}$ sampai $110^{\circ} 03^{\prime} 06^{\prime \prime}$ Bujur Timur di pantai utara Jawa Tengah dan berada pada jalur utama yang menghubungkan JakartaSurabaya. Luas daerah 78.864,16 Ha. Batas-batas wilayahnya sebelah utara Laut Jawa, sebelah timur Kabupaten Kendal, sebelah selatan Kabupaten Wonosobo dan Kabupaten
Banjarnegara, sebelah barat Kota dan Kabupaten Pekalongan. Permasalahan gizi di Provinsi Jawa Tengah masih menjadi prioritas untuk diatasi karena menurut data yang diperoleh dari Pemantauan Status Gizi (PSG) 2016, pada kategori Balita kurus, dengan prevalensi yang seharusnya $<5 \%$, presentase Balita kurus Provinsi Jawa Tengah adalah 9,6\% yang didalamnya termasuk Kabupaten Batang yang memiliki angka persentase cukup tinggi yaitu sebesar 8,8\%. (Dinas Kesehatan Kabupaten Batang 2019)

Pelaporan yang dilakukan oleh dinas kesehatan Kabupaten Batang, Kasus gizi buruk di Batang masih melebihi rata-rata Provinsi Jawa Tengah yaitu sebesar 97 kasus meskipun angka ini mengalami penurunan dari tahun lalu sebesar 129 kasus. Sedangkan untuk 
prevalensi Balita yang masuk dalam kondisi kekurangan gizi dengan ditandai dengan prevalensi balita yang berada di Bawah Garis Merah (BGM) adalah sebesar 806 kasus yang meningkat dari tahun kemarin, yang mencapai angka 746 kasus. (Dinas Kesehatan Kabupaten Batang 2016)

Penelitian ini dimaksudkan untuk mempermudah memahami wilayah-wilayah yang menjadi lokus daerah rawan gizi bermasalah dengan menggunakan analisis spasial.

\section{Sebaran Kejadian Gizi Buruk di Kabupaten Batang}

Gambaran kejadian gizi buruk pada balita yang tersebar di wilayah di Kabupaten Batang diklasifikasikan menjadi 3 kategori yaitu tinggi, sedang dan rendah. Daerah yang memiliki balita dengan kejadian gizi buruk yang tinggi adalah sebesar 24,41 \% sampai dengan $36,08 \%$ dan ditandai dengan daerah dengan warna merah. Sedangkan Daerah yang mengamiliki balita dengan kejadian gizi buruk sedang antara 12,72 $\%$ sampai dengan 24,40\% dan ditandai dengan daerah dengan warna kuning. Sedangkan Daerah yang mengamiliki balita dengan kejadian gizi buruk rendah antara 1,03\% sampai dengan $12,71 \%$ dan ditandai dengan daerah dengan warna hijau.

Wilayah yang tergolong kasus kejadian gizi buruk tinggi adalah di wilayah kecamatan Batang (Pusk. Batang I, II, III dan IV) dengan total presentase kejadian 36,08 \% . Sedangkan wilayah yang tergolong kasus gizi buruk sedang tidak ditemukan, sedangkan wilayah yang tergolong kasus gizi buruk rendah ditemukan di hampir seluruh wilayah, wilayah tersebut tersebar di 13 wilayah seperti: Kec. Pecalungan, Kec. Warungasem, Kec.Wonotunggal, Kec. Bawang, Kec.Limpung, Kec.Subah, Kec.Reban,Kec.Gringsing, Kec.Bandar, Kec.Kandeman, Kec.Tulis, Kec.Blado, Kec.Banyuputih. Sedangkan untuk kecamatan yang tidak ada kasus gizi buruk adalah di Kec. Tersono.

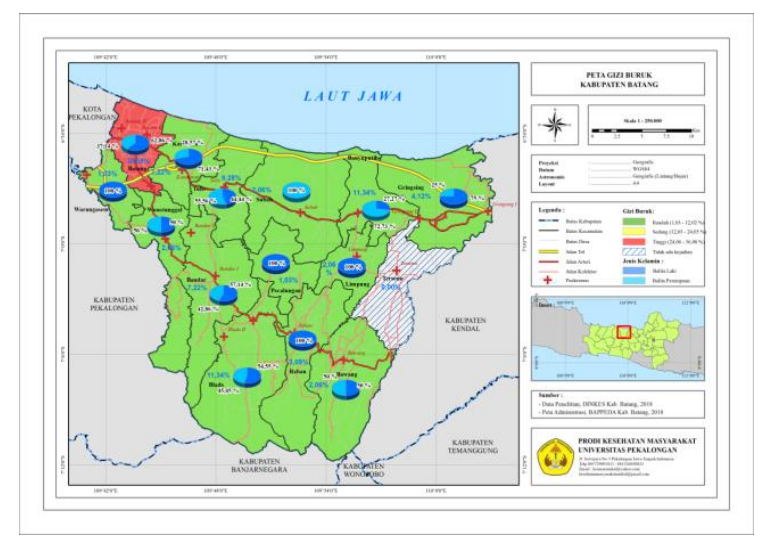

Peta 1. Peta Sebaran Kasus Gizi Buruk di Kabupaten Batang

Sebaran Balita yang berada di Bawah Garis Merah (BGM) 
Gambaran balita yang kondisinya masih berada di Bawah Garis Merah tersebar merata di Kabupaten Batang dan menurut data presentase kejadiannya meiningkat dari tahun kemarin dari 746 balita di tahun 2017, meningkat sbesar 806 balita di tahun 2018. Dalam penelitian ini wilayah dengan angka kejadian Balita Bawah Garis Merah (BGM) diklasifikasikan menjadi 3 kategori yaitu tinggi, sedang dan rendah. Daerah yang memiliki balita dengan kondisi BGM tinggi sebesar $11,42 \%$ sampai dengan $16,05 \%$. Sedangkan Daerah yang memiliki balita dengan kondisi BGM sedang antara $6,34 \%$ sampai dengan $11,41 \%$ dan ditandai dengan daerah dengan warna kuning. Sedangkan Daerah yang memiliki balita dengan kondisi BGM yang renah/sedikit antara 1,24\% sampai dengan $6,33 \%$ dan ditandai dengan daerah dengan warna hijau. Wilayah yang tergolong kasus balita mengalami BGM tinggi tersebar di 2 kecamatan adalah di wilayah Kecamatan Blado (termasuk wilayah puskesmas Blado I, II) sebesar $12,16 \%$ dan Kecamatan Batang (termasuk wilayah puskesmas Batang I, II,III dan IV) sebesar 16,50 \%. Sedangkan wilayah yang tergolong kasus balita mengalami BGM sedang tersebar di 6 wilayah adalah di Kec. Pecalungan $(5,58 \%)$, Kec.Kandeman $(6,58 \%)$, Kec. Bandar (8,06 \%), Kec. Bawang (8,06 \%), Kec. Subah (8,06\%), Kec. Banyuputih (8,44 \%). Sedangkan wilayah yang tergolong kasus balita mengalami BGM rendah tersebar di 7 kecamatan adalah di wilayah Kec. Warungasem (1,24 \%) dan Kec. Limpung sebesar (2,98\%), Kec.Reban $(3,47 \%)$, Kec. Wonotunggal (3,60\%), Kec. Tulis $(4,84 \%)$, Kec. Tersono (5,09 $\%)$, Kec. Gringsing (5,33\%).

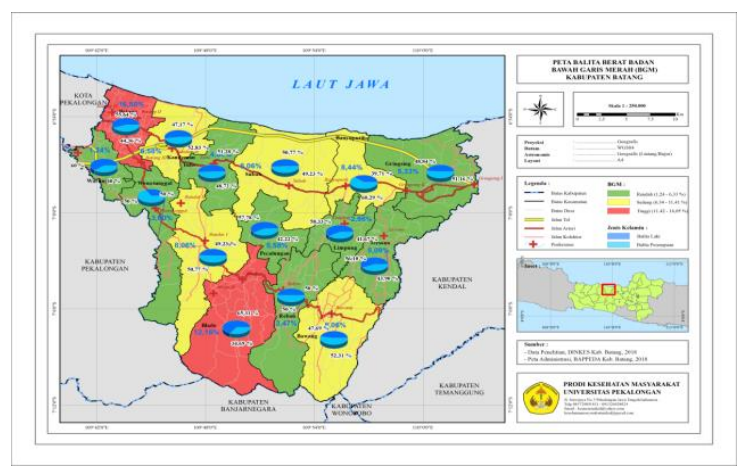

Peta 2. Sebaran kasus balita BGM di Kabupaten Batang

\section{Sebaran Bayi dengan kondisi Berat}

\section{Bayi Lahir Rendah (BBLR)}

Sebaran bayi BBLR terdeteksi pada daerah-daerah tertentu saja. Dalam penelitian ini wilayah dengan kasus Berat Bayi Lahir Rendah (BBLR) diklasifikasikan menjadi 3 kategori yaitu tinggi, sedang dan rendah. Daerah yang memiliki kasus BBLR tinggi memiliki presentase sebesar 14,37\%-20,13\%. 
Sedangkan daerah yang memiliki kasus BBLR sedang berada pada presentase sebesar $8,61 \%-14,36 \%$ serta ditandai dengan daerah dengan warna kuning. Dan daerah yang memiliki kasus BBLR rendah berada pada presentase sebesar $2,83 \%-8,60 \%$ dan ditandai dengan daerah dengan warna hijau. Wilayah yang tergolong memiliki kasus (BBLR) tinggi terdapat di kecamatan Batang yang termasuk di 4 wilayah kerja puskesmas yaitu (Puskesmas Batang 1, II dan IV) memiliki angka kasus BBLR sebesar 20,13 \%. Sedangkan wilayah yang tergolong memiliki kasus Berat Bayi Lahir Rendah (BBLR) sedang terdapat diwilayah Kecamatan Bandar Kab. Batang dengan angka kasus sebesar $9,82 \%$. Sedangkan wilayah yang tergolong memiliki kasus Berat Bayi Lahir Rendah (BBLR) rendah tersebar di 13 kecamatan yaitu, wilayah Kec. Bawang, Kec. Warungasem (7,32 \%), Kec. Kandeman (6,82 \%), Kec. Blado $(6,16 \%)$, Kec. Gringsing (5,66\%), Kec. Tersono (5,66 \%), Kec. Wonotunggal (5,49 \%), Kec. Limpung (5,16 \%), Kec. Subah (4,83 \%), Kec. Pecalungan (4,33 $\%)$, Kec. Banyuputih (4,33 \%), Kec. Reban $(3,83 \%)$, Kec. Tulis $(2,83 \%)$. Menurut analisis yang ada, wiayah yang memiliki pkasus Berat Bayi Lahir
Rendah (BBLR) paling rendah adalah di Kecamatan Tulis Kab. Batang

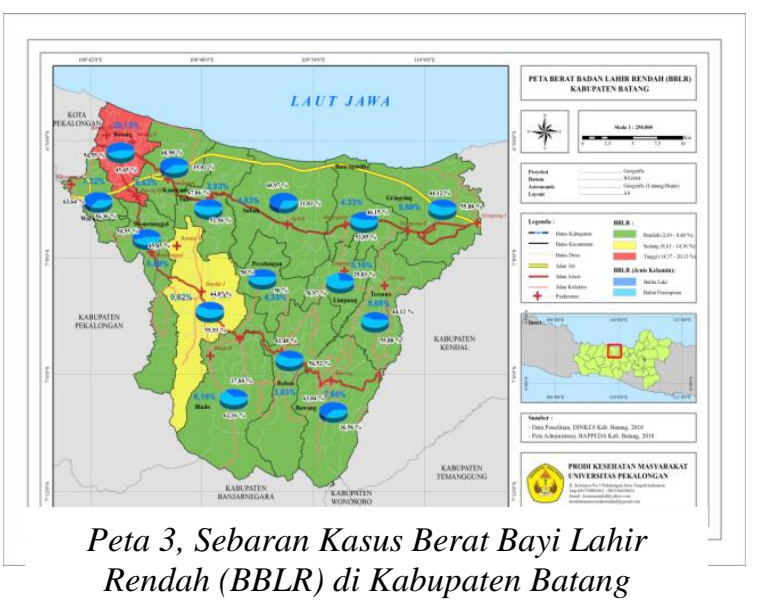

\section{Daerah Rawan Status Gizi}

\section{Bermasalah}

Daerah yang akan menjadi daerah rawan status gizi bermasalah adalah daerah yang merupakan hasil overlay antara peta sebaran kasus gizi buruk, sebaran balita BGM dan wilayah dengan kasus Berat Bayi Lahir Rendah (BBLR). Peta menggambarkan daerah rentan yang mengalami status gizi bermasalah dengan perpaduan 3 angka kasus tersebut. Variabel yang diambil antara lain adalah kasus Gizi Buruk dikarenakan daerah yang memiliki angka kasus gizi buruk tinggi yang diukur dari membandingkan berat badan balita dengan umur (BB/U) gambarannya adalah jika $(\mathrm{BB} / \mathrm{U})$ balita tidak sesuai dengan ideal perkembangannya maka dapat dikatakan 
mengalami gizi buruk dengan hasil $\mathrm{Z}$ Score <-3 SD. Meskipun sebenarnya untuk penyebab gizi buruk ini memiliki berbagai macam faktor, yang termasuk determinan langsung yaitu intake/asupan makanan yang kurang dan riwayat penyakit infeksi. Variabel selanjutny adalah kasus balita yang berada di Bawah Garis Merah (BGM) yang tersebar cukup merata di sebagian besar wilayah kecamatan Batang dan variabel ini juga dapat menjadi indikator wilayah yang bisa dikategorikan rawan status gizi bermasalah. Penilaian BGM ini dapat didasarkan pada perkembangan BB balita yang dapat terpantau dari Kartu Menuju Sehat (KMS). Jika Berat Badan balita masih berada di pita warna hijau dapat dipersepsikan memiliki gizi yang baik, sedangkan jika berat badan balita berada dibawah pita merah maka itu merupakan salah satu "warning" atau peringatan terhadap ibu kaitannya dengan BB anak yang tidak mengalami kenaikan dalam satu bulan terakhir. Dan jika kondisi tersebut berulang sampai 3 bulan pengukuran maka perlu adanya tindak lanjut. (Departemen Kesehatan Republik Indonesia 2010)

Akan tetapi perlu diperjelas bahwa KMS ini hanya menggambarkan pola pertumbuhan berat badan balita ,bukan merupakan patokan status gizi balita yang akurat dan tetap untuk pengukuran antropometri didasarkan pada pengukuran $\mathrm{Z}$ score yang pedomannya dapat dilihat pada Buku Saku Antropometri tahun 2010. (Kementrian Kesehatan Republik Indonesia 2010)

$$
\text { Variabel yang juga diambil }
$$
dalam analisis penelitian ini adalah kasus Berat Badan Lahir Rendah (BBLR) yang terjadi di Kabupaten Batang, alasan mengapa variabel BBLR ini diambil karena jika suatu wilayah memiliki kasus BBLR tinggi maka daerah tersebut juga termasuh daerah rawan status gizi bermasalah, dan munculnya kasuus BBLR yang tinggi ini juga dapat dipengaruhi oleh intake ibu saat hamil, kondisi kesehatan ibu (status ibu dengan kondisi Kekurangan Energi Kronis) menurut penelitian Fajariana 2018, menunjukkan bahwa ibu yang selama hamil mengalami KEK memiliki faktor resiko 6,6 kali lebih besar melaiharkan bayi dengan BBLR. (Fajarina 2018)

Variabel yang juga berpengaruh terhadap BBLR menurut adalah Paritas, kunjungan pemeriksaan kehamilan dan asupan zat besi saat hamil. (Afifah 2017). Berdasarkan analisis dalam penelitian ini untuk klasifikasi atau 
pengelompokan daerah dilakukan menjadi 3 yaitu, daerah yang berpotensi "tinggi" rawan gizi bermasalah ditandai dengan daerah warna merah, sedangkan daerah yang berpotensi "sedang" mengalami gizi bermasalah ditandai dengan warna kuning, lalu daerah yang berpotensi "rendah" mengalami gizi bermasalah ditandai dengan warna hijau. Daerah yang tergolong rawan gizi bermasalah paling tinggi berada di Kecamatan Batang yang meliputi 4 wilayah kerja puskesmas yaitu Puskesmas Batang 1, Puskesmas Batang II, Puskesmas Batang IV dan sebagian Puskesmas Batang III. Sedangkan daerah dengan status gizi bermasalah "sedang" berada di wilayah Kecamatan Blado (meliputi wilayah kerja Puskesmas Blado I dan II) dan Kecamatan Bandar (meliputi wilayah kerja Puskesmas Bandar I dan Bandar II).

Berdasarkan analisis, wilayah yang menjadi wilayah rawan status gizi bermasalah berada di daerah pesisir dan daerah pegunungan. Daerah berstatus rawan gizi bermasalah "tinggi" berada di wilayah pesisir. Hal ini dapat dikarenakan karakteristik wilayah pesisir yang seringkali mengalami bencana ROB (air laut pasang) yang sering terjadi di pesisir Pekalongan sampai dengan Batang, sebagian dan juga mata pencaharian warganya lebih didominasi nelayan, sehingga konsumsi makanan yang mengandung gizi yang seimbang kurang. Selain itu berkaitan dengan pekerjaan sebagin besar warga selain nelayan akan tetapi juga menjadi buruh lepas di luar kota sehingga anak mereka hanya tinggal dengan nenek atau anggota keluarga yang lain sehingga kemungkinan jika tinggal dengan nenek maka asupan gizi kurang diperhatikan. Tingkat pendidikan juga berpengaruh terhadap apa yang dimakan atau intake dari balita tersebut. Kebiasaan makan dengan lauk yang hanya 1 jenis yang bahkan tidak ditambahkan sayur juga menjadi faktor utama tidak terpenuhinya asupan gizi dalam tubuh. Wilayah yang mengalami rawan gizi bermasalah sedang berada di kecamatan Blado dan Bandar. Dua kecamatan ini termasuk wilayah pegunungan, hal yang menjadi penyebab banyaknya kasus gizi yang bermasalah antara lain ketersediaan bahan makanan untuk dikonsumsi meskipun banyak jenisnya. akan tetapi kemampuan atau daya beli masyarakat daerah pegunungan cukup rendah, hal ini sejalan dengan hasil penelitian dari Rifqi, 2015 yang menjelasakan bahwa 
Kecamatan Blado Kabupaten Batang termasuk daerah rawan pangan, dari 20 kecamatan sebanyak 15 kecamatan merupakan daerah rawan pangan dan masyarakat juga hanya memasak bahan makanan yang dapat di hangatkan untuk beberapa kali makan seperti sayur lodeh, yang kemungkinan bisa dikonsumsi lebih dari 2 kali, jika dilihat dari kandungan gizi yang ada pada makanan tersebut sudah dipastikan rusak sejalan dengan perumusan jejaring gizi bermasalah yang dikeluarkan oleh World Health Organisation (WHO) bahwa faktor penyebab langsung dari permasalahan gizi yang terjadi adalah masalah Intake (Asupan makanan) dan riwayat penyakit, sedangkan penyebab yang tidak langsung adalah dari pendidikan, sosial ekonomi. (UNICEF (WHO) 2015)

Tabel.4 Variabel Daerah Dengan Status Gizi Bermasalah

\begin{tabular}{|l|c|c|c|c|c|c|c|}
\hline Kecamatan & $\begin{array}{c}\text { Kasus } \\
\text { Gizi } \\
\text { Buruk } \\
(\%)\end{array}$ & Bobot & $\begin{array}{c}\text { Kasus } \\
\text { BGM(\%) }\end{array}$ & Bobot & $\begin{array}{c}\text { Kasus } \\
\text { BBLR(\%) }\end{array}$ & Bobot & $\begin{array}{c}\text { Jumlah } \\
\text { Bobot }\end{array}$ \\
\hline Warungasem & 1,03 & 1 & 1,24 & 1 & 7,32 & 1 & 3 \\
\hline Limpung & 2,06 & 1 & 2,98 & 1 & 5,16 & 1 & 3 \\
\hline Reban & 3,09 & 1 & 3,47 & 1 & 3,83 & 1 & 3 \\
\hline Wonotunggal & 2,06 & 1 & 3,60 & 1 & 5,49 & 1 & 3 \\
\hline Tulis & 9,28 & 1 & 4,84 & 1 & 2,83 & 1 & 3 \\
\hline Tersono & 0,00 & 0 & 5,09 & 1 & 5,66 & 1 & 2 \\
\hline Gringsing & 4,12 & 1 & 5,33 & 1 & 5,66 & 1 & 3 \\
\hline Pecalungan & 1,03 & 1 & 5,58 & 2 & 4,33 & 1 & 4 \\
\hline Kandeman & 7,22 & 1 & 6,58 & 2 & 6,82 & 1 & 4 \\
\hline Bandar & 7,22 & 1 & 8,06 & 2 & 9,82 & 2 & 5 \\
\hline Bawang & 2,06 & 1 & 8,06 & 2 & 7,65 & 1 & 4 \\
\hline Subah & 2,06 & 1 & 8,06 & 2 & 4,83 & 1 & 4 \\
\hline Banyuputih & 11,34 & 1 & 8,44 & 2 & 4,33 & 1 & 4 \\
\hline Blado & 11,34 & 1 & 12,16 & 3 & 6,16 & 1 & 5 \\
\hline Batang & 36,08 & 3 & 16,50 & 3 & 20,13 & 3 & 9 \\
\hline
\end{tabular}

\section{SIMPULAN}

Dari hasil penelitian maka dapat disimpulkan bahwa:
1. Daerah yang tergolong memiliki kasus gizi buruk tinggi adalah adalah di wilayah kecamatan 
Batang sebesar 36,08 \% meliputi (Pusk. Batang I, II, III dan IV)

2. Daerah yang tergolong memiliki kasus balita BGM tinggi tersebar di 2 kecamatan adalah wilayah Kecamatan Blado sebesar 12,16 $\%$ (termasuk wilayah puskesmas Blado I, II) dan Kecamatan Batang sebesar 16,50 \%. (termasuk wilayah puskesmas Batang I, II,III dan IV)

3. Daerah yang tergolong memiliki kasus Berat Bayi Lahir Rendah (BBLR) tinggi terdapat di kecamatan Batang yang termasuk di 4 wilayah kerja puskesmas yaitu (Puskesmas Batang 1, Puskesmas Batang II dan Puskesmas Batang IV) memiliki angka kasus BBLR sebesar $20,13 \%$.

4. Daerah yang tergolong rawan gizi bermasalah paling tinggi berada di Kecamatan Batang yang meliputi 4 wilayah kerja puskesmas yaitu Puskesmas Batang 1, Puskesmas Batang II, Puskesmas Batang IV dan sebagian Puskesmas Batang III.

\section{SARAN}

Intervensi khusus dilakukan pada daerah yang menjadi lokus rawan status gizi bermasalah dengan:

1. Optimalisasi Posyandu

2. Home Visit berkala pada keluarga yang memiliki permasalahan gizi.

3. Sinergi 4 pilar (kesehatan, pertanian, ekonomi dan pendidikan) harapannya secara kompleks dapat mengatasi permasalahan gizi secara menyeluruh.

\section{UCAPAN TERIMAKASIH}

Ucapan terimakasih peneliti ucapkan kepda jajaran Dinas Kesehatan Kabupaten Batang yang telah memfasilitasi peneitian ini dan juga pelatih LPK Sinau GIS yang telah memberikan ketrampilan dalam olah data overlay.

\section{DAFTAR PUSTAKA}

Afifah, N., 2017. Faktor Resiko yang berhubungan dengan kejadian berat badan lahir rendah studi kasus di kecamatan wanasari kabupaten brebes.

Astrini, Retno, P.O., 2012. Modul Pelatihan Quantum GIS Tingkat Dasar 1st ed., Mataram: Bappeda Provinsi NTB.

Bohrer, Gill, Shachar Shem, E.S., 2002. The Effectivenes of Various Rabies Spatial Vaccination Patthern in a 
simulated Host Population With

Compled Distribution. Ecological Modelling, 152(2), pp.205-211.

Departemen Kesehatan Republik

Indonesia, 2010. Klasifikasi

Penilaian Status Gizi, Jakarta.

Dinas Kesehatan Kabupaten Batang, 2016. Pemantauan Status Gizi (PSG), Batang Jawa Tengah.

Dinas Kesehatan Kabupaten Batang, 2018. Profil Kesehatan Dinas Kesehatan Kabupaten Batang, Batang Jawa Tengah.

Dinas Kesehatan Kabupaten Batang, 2019. Profil Kesehatan Kabupaten Batang, Batang Jawa Tengah.

Fajarina, A., 2018. Faktor Resiko yang berhubungan dengan kejadian BBLR di Kec. Semampir Surabaya. Media Gizi Indonesia, 13(1), pp.71-80.

Kementrian Kesehatan Republik Indonesia, 2010. Buku Saku Antropometri, Kementrian Kesehatan RI.

Kementrian Kesehatan Republik Indonesia, 2019. Indeks Pembangunan Masyarakat Membaik, Jakarta.

Kementrian Kesehatan Republik Indonesia, 2018. Riset Kesehatan Dasar 2018, Jakarta.

Kementrian Kesehatan Republik Indonesia, 2016. Survey Indikator Kesehatan Nasional, Laurini, R. \& Thompson, D., 1992. Spatial Knowledge. In Fundamentals of Spatial Information Systems. pp. 620-670. Prahasta, E., 2001. Konsep Konsep Dasar Sistem Informasi Geografis. CV.INFORMATIKA, p.333.
UNICEF (WHO), 2015. The World bank joint child malnutrition estimates. Available

at: http://apps.who.int/gho/data/view. main.NUTUNUNDERWEIGHTv? lang=en [Accessed March 20, 2015]. 